\title{
Auditing in the Age of COVID-19: Waste of Resources or an Opportunity We Cannot Afford to Waste?
}

This article was published in the following Dove Press journal: Clinical Audit

\author{
Douglas Stangoe (iD \\ Zoka Milan (1D \\ Kings College Hospital, London, UK
}

Correspondence: Douglas Stangoe Kings College Hospital, Denmark Hill, London, UK

Email douglas.stangoe@nhs.net
The SARS-CoV-2 virus identified in late 2019 has had a devastating impact on healthcare around the world through a pandemic unparalleled in living memory. Whilst no two nations have undertaken an identical response to the crisis, sociological and economic lockdowns have occurred in many countries to quell the exponential growth in infections with healthcare systems rapidly and comprehensively overhauled. Thankfully, these measures have lead many countries to report a downturn in new cases. However, uptrending infections continue in others and the prospect of subsequent surges of disease hangs over us all until the discovery, and distribution, of an effective vaccine which itself is far from guaranteed. The sweeping changes in healthcare mandated by the pandemic in recent months have occurred primarily to enable clinicians to cope with soaring demand but also to minimise the disease's spread within hospitals themselves. Medical staff of all flavours have been redeployed to critical care and other COVID-19 treatment areas. Extra intensive care units, both within existing hospitals and in massive new hospitals, have been built at breakneck speed. Non-essential clinical work has been halted and retired medics asked to return to the frontline of the battle with our new enemy. Whilst such action has been essential, the toll the pandemic has taken on the global medical fraternity is huge. In July it was reported that there had been at least 3000 COVID-19 deaths amongst healthcare workers, with well over 500 in England and Wales alone, ${ }^{1}$ with underreporting likely to render the true figure far higher. The soaring infection rates in some countries of more limited resources render further losses from within our ranks inevitable. In addition, the psychological consequences of an about turn in one's working practices, labour intensity and sheer scale of mortality, particularly of those isolated from their loved ones, has wrought profound psychological consequences on our colleagues; suicides have been reported and burnout has been widespread. ${ }^{2}$ The political debate about the effectiveness of the response and the responsibility for such tragedies will surely rumble on for years to come. Against this backdrop it is easy to conclude that audit is simply not a priority and, like so many staff, our efforts are best redeployed to areas of greater need. Indeed, much of the traditional fodder that lends itself well to audit, such as elective surgery and outpatient clinics, have been massively scaled down or stopped altogether as part of national response strategies.

However, such views are mistaken. If clinical governance, of which audit is a fundamental component, is essential in normal times and has rightly earned its place in all aspects of modern medicine, the uncharted waters of the ongoing 
COVID-19 pandemic surely elevates its importance still further. Given the accelerating spread of the virus in many areas, the ongoing absence of a vaccine and the prospect of subsequent waves of infection, the importance of a readily undertaken process to improve all aspects of our response to the pandemic presents an opportunity we can ill afford to pass up. Indeed, the sheer scale of this response provides a plethora of areas well suited to the audit process. Further, the heartening sharing of research and crossborder pooling of expertise has doubtless saved countless lives and a huge debt is owed to those clinicians who have been involved with this. The findings of COVID-19 related audits are no different and sharing knowledge gleaned through the audit process through media such as this journal could comprise an important part of our global reaction.

In the UK and Europe, the heavy burden of COVID-19 infection is, in most areas, abating and the lockdowns which have contributed to this fall are gradually being withdrawn. In hospitals, the clinical work suspended to enable providers to cope with the pandemic is returning and, thus, so too is the opportunity for those audits which may have been put on hold when that work was suspended. Indeed, the return of such activity and hospitals attenuating the exclusivity of their focus on treating COVID-19 will likely enable new, nonCOVID related audits to be undertaken and those audits adjourned early in the pandemic could perhaps now be resumed. Given the backlog of such work that now exists, the potential for larger more robust audits is an exciting one. Alas, just as we must be able to return to our normal clinical work, we must too be able to undertake audit of both COVID-19 and unrelated subjects.
Despite progress in suppressing the disease, it remains an omnipresent menace and will do so for some time yet. Like so many other aspects of life, it seems inevitable that the conduct of audit will be very different from before. For instance, those audits which require minimal interpersonal contact will perhaps be favoured over those which are less suited to the social distancing requirements to which we have had to become familiar. Furthermore, the novel approaches used in other areas to enable productivity without risking infection could be applied to the auditing process.

Virtually no area of medicine is unchanged by the demands of the COVID-19 era in which we live, and the field of clinical audit is no exception. However, with so much still to learn about its optimal clinical management, the likelihood of future pandemics and the need to resume our previous workload, the insight afforded by audit renders its deployment essential now more than ever. Alas, the Herculean response to COVID-19 should not preclude auditing and clinical governance. On the contrary, they are an integral part of it.

\section{Disclosure}

The authors report no conflict of interest in this work.

\section{References}

1. Amnesty International. Exposed, silenced, attacked: failures to protect health and essential workers during the COVID-19 pandemic; 2020. Available from: www.amnesty.org/download/Documents/ POL4025722020ENGLISH.PDF. Accessed July 25, 2020.

2. Gulati G, BD K. Physician suicide and the COVID-19 pandemic. Occup Med (Chic Ill). 2020; kqaa104. doi:10.1093.occmed/kqaa104.
Clinical Audit

\section{Publish your work in this journal}

Clinical Audit is an international, peer-reviewed, open access journal focusing on the processes and outcomes of clinical audit in any area of healthcare. All aspects of patient care are addressed within the journal and practitioners from all disciplines are invited to submit their work. Areas covered include: Publication of audits; How an audit has changed practice; Practical tips on how to do audits and to

Submit your manuscript here: https://www.dovepress.com/clinical-audit-journal

\section{Dovepress}

avoid pitfalls; How audits have changed patient care; Calls and justifications for new audits. The manuscript management system is completely online and includes a very quick and fair peer-review system, which is all easy to use. Visit http://www.dovepress.com/ testimonials.php to read real quotes from published authors. 